\title{
Heat shock proteins as danger signals for cancer detection
} \author{
Sarah Shirley ${ }^{3}$ and Carmen Garrido ${ }^{1,2} *$ \\ 1 Heat Shock Proteins and Cancer, INSERM, UMR 866 IFR 100, Faculty of Medicine, Dijon, France \\ 2 Université de Bourgogne, Dijon, France \\ ${ }^{3}$ Trail Signalling and Cancer, INSERM, UMR 866 IFR 100, Faculty of Medicine, Dijon, France
}

Renaud Seigneuric ${ }^{1,2 *}$, Hajare Mjahed ${ }^{1,2+}$, Jessica Gobbo ${ }^{1,2+}$, Anne-Laure Joly ${ }^{1,2+}$, Kevin Berthenet ${ }^{1,2}$,

Edited by:

Vassiliki Karantza, UMDNJ - Robert

Wood Johnson Medical School, USA

Reviewed by:

Sharon R. Pine, UMDNJ Cancer

Institute of New Jersey, USA

Hilary Ann Coller, Princeton

University, USA

*Correspondence:

Renaud Seigneuric and Carmen

Garrido, Heat Shock Proteins and

Cancer, INSERM, UMR 866 IFR 100,

Faculty of Medicine, 7 Boulevard

Jeanne d'Arc, 21000 Dijon, France.

e-mail: renaud.seigneuric@

u-bourgogne.fr;

cgarrido@u-bourgogne.fr

${ }^{\dagger}$ Renaud Seigneuric, Hajare Mjahed, Jessica Gobbo and Anne-Laure Joly

have contributed equally to this work.
First discovered in 1962, heat shock proteins (HSPs) are highly studied with about 35,500 publications on the subject to date. HSPs are highly conserved, function as molecular chaperones for a large panel of "client" proteins and have strong cytoprotective properties. Induced by many different stress signals, they promote cell survival in adverse conditions. Therefore, their roles have been investigated in several conditions and pathologies where HSPs accumulate, such as in cancer. Among the diverse mammalian HSPs, some members share several features that may qualify them as cancer biomarkers. This review focuses mainly on three inducible HSPs: HSP27, HPS70, and HSP90. Our survey of recent literature highlights some recurring weaknesses in studies of the HSPs, but also identifies findings that indicate that some HSPs have potential as cancer biomarkers for successful clinical applications.

Keywords: heat shock protein, danger signal, detection, biomarker, stress, cancer

\section{INTRODUCTION}

Heat shock proteins (HSPs) are important molecular players in the cellular stress response (Macario and Conway de Macario, 2004). They can be divided into five superfamilies according to their molecular weight: small HSPs [or HSPB family with the recent ontology (Kampinga et al., 2009)], HSP40 (DNAJ), HSP70 (HSPA), HSP90 (HSPC), and HSP110 (HSPH). Two main functions have been described for HSPs: firstly, they act as molecular chaperones thereby playing a role in protein folding, aggregation, transport, and/or stabilization. Secondly, they prevent cell death, for instance by preventing post-mitochondrial apoptosis in caspase-dependent (e.g., HSP27, HSP70, and HSP90) and/or independent (e.g., HSP70) pathways (Gallucci and Matzinger, 2001). HSPs were first discovered in Drosophila melanogaster as a set of proteins whose expression was induced by heat shock. They are highly conserved proteins, present in the three domains of life: archaea, bacteria, and eukaryotes (Macario and Conway de Macario, 2004). HSPs are now also called stress proteins since their expression was found to be induced in response to a wide variety of physiological and environmental insults allowing cells to survive to otherwise lethal conditions. Stressors can be physical and chemical insults such as radiation, including ultraviolet light and magnetic fields, compression, shearing and stretching, hypoxia, $\mathrm{pH}$ shift, nutrient deprivation, or exposure to reactive oxygen species, alcohols, or metals. They also include biological insults such as fever, cold, infection, inflammation, diseases including cancer, cardiac diseases, and neurodegenerative disorders. Cellular stress can also be triggered by treatments with anticancer drugs or antibiotics (Ciocca and Calderwood, 2005; Macario and
Conway de Macario, 2005; Garrido et al., 2006; Jego et al., 2010; Willis and Patterson, 2010; Macario et al., 2011). HSPs are reported to be overexpressed in several pathologies. As such, members of the large HSP family are studied widely as they may represent interesting biomarker candidates. Chaperones such as HSP70 and HSP90 tend to be team-players, acting together with other chaperones and cochaperones (Macario and Conway de Macario, 2005). Chaperone-cochaperone complexes such as HSP70, HSP40, and nucleotide-exchange factor are able to help nascent polypeptide chains to fold properly, refold damaged molecules, and can also direct proteins to a protein-degrading mechanism such as the ubiquitin-proteasome system (Lanneau et al., 2010). Each HSP is localized in one or a set of specific compartment(s). For instance, HSP70 and HSP90 can be present in the cytosol and the nucleus, whereas HSP60 is found in mitochondria (see Figure 1) and grp78 (Bip, or HSPA5) in the endoplasmic reticulum. Microorganisms may be another source of detectable HSPs. Indeed, humans may be considered as a "superorganism," colonized by around a thousand different species of microorganisms. These are mostly bacterial cells present in the intestinal tract. These bacterial cells outnumber our cells by at least a factor of 10 , (the total number of cells comprising the adult human body, both native and foreign, being estimated to $\sim 10^{14}$ ) and their genes outnumber our own by a factor of 100. These HSPs from microorganisms often induce a proinflammatory response. Thus, when measuring anti-HSP levels, especially against a conserved constitutive chaperone such as HSP60, it is important to consider the protein may originate from microorganisms. In this review we will focus on HSP60 and the three most inducible HSPs: HSP27, HSP70, and HSP90. 


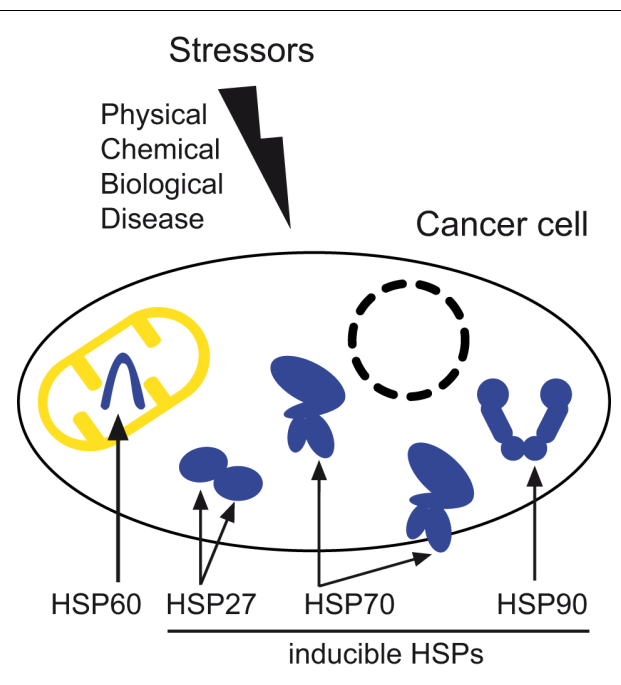

FIGURE 1 | Stressors of physical, chemical, or biological origin, as well as diseases such as cancer can induce the accumulation of heat shock proteins necessary for the survival of cancer cells. This scheme illustrates the main localizations of HSP60, present in the mitochondria, and the three inducible cytosolic/nuclear HSPs: HSP27, HSP70 (also found in the cell membrane), and HSP90.

\section{EXTRACELLULAR HSPs: CIRCULATING AND MEMBRANE-BOUND HSPs}

Due to their lack of a transmembrane domain, HSPs are considered intracellular soluble proteins (Gallucci and Matzinger, 2001) that can be induced by a wide panel of stress signals and have strong protective properties. However, HSPs such as HSP27, HSP60, HSC70, HSP70, and HSP90 can also be found in the extracellular environment where their role is believed to be immunogenic (Schmitt et al., 2007). How HSPs are found in the extracellular medium is still a debated issue. HSPs lack the consensus signal for secretion via the classical Golgi pathway. The first hypothesis was attributed to spontaneous cell death leading to HSP extravasation (Basu et al., 2000). However, it was found that undamaged, live cells released HSP70 by an active non-classical secretory pathway that was not affected by ER Golgi system inhibitors such as brefeldin A (Hightower and Guidon, 1989; Hunter-Lavin et al., 2004). Thus, active release of HSP70 might occur through one or more alternative mechanisms (Nickel and Seedorf, 2008). Different pathways have also been proposed for HSP70 release: a lysosome-endosome pathway (Mambula and Calderwood, 2006) or a release by secretory-like granules (Evdonin et al., 2006), but the bulk of the evidence points to an insertion of HSP70 oligomers into the lipid bilayer of export vesicles. These oligomers form ATPdependent ion channels, leaving only a small C-terminal region of the protein outside (Vega et al., 2008). Thus, several mechanisms have been proposed to account for the release of these HSPs into biofluids, however the question remains unresolved (Didelot et al., 2007; Joly et al., 2010; De Maio, 2011).

Some HSPs can also be found on the cell surface, such as HSP70. This has been widely reported in a variety of conditions, especially for cancer and immune cells (De Maio, 2011). For cell surface display to occur, a high intracellular HSP level is thought to be necessary. For display of HSP70, for example, only about $10 \%$ of the intracellular HSP70 is translocated to the cell membrane. The high specificity of HSP70 and HSC70 for membranes seems to be related to membrane fluidity and thus to lipid composition of the bilayer, due to affinity for phosphatidylserine and cholesterol (Arispe et al., 2004; Schilling et al., 2009). Presence of HSP70 in the membranes was stable even when treated with non-ionic detergent, suggesting its insertion into lipid rafts (Hunter-Lavin et al., 2004; Vega et al., 2008). In contrast to intracellular HSPs that mainly play a cytoprotective role, some extracellular HSPs such as HSP27 and HSP70, have immunogenic properties (Didelot et al., 2007) and may induce either a pro- or an anti-inflammatory response. Because cell membranes can contain a certain amount of HSPs, exosomes, and other vesicles derived from these membranes also harbor HSPs on their membranes. For example, membranebound HSP70 in vesicles were shown to activate macrophages (Vega et al., 2008). We have recently shown that tumor-derived exosomes harboring HSP70 in the membrane triggered STAT3 activation in myeloid-derived suppressive cells, leading to tolerance of the immune system to the tumor cells (Chalmin et al., 2010). Such tumor-derived exosomes displaying HSPs may provide interesting options for cancer detection and need to be further explored.

\section{BIOMARKERS}

A useful biomarker needs to fulfill several criteria (Seigneuric et al., 2010). It should ideally be at least: (i) overexpressed and positively associated with the pathology of interest in order to identify cases, (ii) specific to the pathology of interest, (iii) relatively easy to measure, ideally by non-invasive assays, and (iv) induced as early as possible to enable early detection.

The most widely used techniques for the investigation of extracellular HSPs as cancer biomarkers have been: immunohistochemical (IHC) stainings to detect the presence of a given HSP from a biopsy, tissue microarrays (TMA), western blot (WB) analysis, and enzyme-linked immunosorbent assay (ELISA), which allows HSP levels to be quantified down to a few nanograms per milliliter, but requires labels that may denature the protein of interest.

\section{HSP27}

HSP27 belongs to the small heat shock protein family. Its structure and function are thought to be modulated by phosphorylation mediated by MAPK2. Intracellular HSP27 plays an anti-apoptotic role through interaction with Bid or cytochrome c (Bruey et al., 2000) and also has a main role as a chaperone, preventing the aggregation of misfolded proteins. As such, HSP27 may contribute to the pathogenesis of human diseases such as cancer, autoimmune diseases, neurological disorders (e.g., Alzheimer's disease), and cardiovascular diseases, where HSP27 has been investigated as a biomarker for myocardial ischemia (Ghayour-Mobarhan et al., 2011). In the context of oncology, HSP27 has been detected in both the intracellular and extracellular environment. An increased level of HSP27 has been reported in ovarian cancer, and more frequently in prostate and breast cancers. Overexpression of HSP27 was found to correlate with poor prognosis for patients with these diseases (Langdon et al., 1995; Calderwood, 2010; Khalil et al., 2011). HSP27 was also reported to contribute to invasion and metastasis (Xu et al., 2006), suggesting that HSP27 could be a biomarker for the diagnosis of cancer (Lee et al., 2005). 
In a study of biopsy samples from prostate cancer patients, expression of intracellular HSP27 was reported using IHC stainings (see Table 1). It was observed that HSP27 expression in prostate cancer tissue was up-regulated compared to the controls (Miyake et al., 2006). Similar qualitative results were also obtained in breast cancer (Rui et al., 2003). HSP27 levels in serum and/or tumor microenvironment were determined by ELISA. Serum levels of HSP27 were significantly higher $(P<0.001)$ in breast cancer patients $(1,038.38 \pm 155.37 \mathrm{pg} / \mathrm{mL}$; $n=32)$ compared to healthy controls $(256.29 \pm 54.01 \mathrm{pg} / \mathrm{mL}$; $n=26)$. Interestingly, HSP27 released by patients' tumor cells were significantly greater $(P<0.0001)$ than that measured in the serum with $24,220 \pm 4,796 \mathrm{pg} / 10^{6}$ cells $/ \mathrm{mL}(n=7)$ and $1,459 \pm 471 \mathrm{pg} / 10^{6}$ cells/mL $(n=7)$, respectively. Another study of breast cancer patients showed that HSP27 levels in the interstitial fluid isolated from primary breast tumor could be extremely high: $2,615,428 \pm 566,442 \mathrm{pg} / \mathrm{mL} ;(n=7)$. This concentration was more than: 2,500-fold higher than that detected in patients' serum, more than 100-fold that of patients' breast tumor culture supernatants, and more than 25-fold higher than the HSP27 level detected in the normal breast tissue interstitial fluid $(103,600 \pm 35,702 \mathrm{pg} / \mathrm{mL})$. Although the number of patients was very small $(n=3)$, this preliminary study suggests highly elevated levels of soluble HSP27 in the human primary breast tumor microenvironment (Banerjee et al., 2011). It would be interesting to confirm this finding with a larger cohort of patients.

\section{HSP60}

HSP60, initially called chaperonin, was one of the first chaperones studied. It plays an essential role in the transport and folding of mitochondrial proteins, and is reported to be associated with different cancers (see Table 2).
Clinical data from patients with localized and locally advanced prostate cancer showed an association between IHC expression of HSP60 and tumor progression. HSP60 expression was also reported to be highly associated with androgen independence in the group of locally advanced cancers with androgen ablation (Castilla et al., 2010). The intensity and extent of immunoreactivity of HSP60, estimated by TMA analyses, significantly predicted biochemical recurrence. It was shown that, for patients with intense HSP60 staining in biopsy, recurrence-free survival was shorter than in those with weak expression (Glaessgen et al., 2008). A study performed in human prostate cancers indicates that HSP60 expression assessed via IHC increases in both early and advanced prostate cancer when compared with non-neoplastic prostatic epithelium (Cornford et al., 2000). The semi-quantitative evaluation of HSPs expression level showed no association with Gleason score neither for the early nor for the advanced cancers. Data from WB analyses of whole lysates in prostate cancer cell lines was consistent with data from tissue specimens. Indeed, each of the malignant cell lines tested showed an increased HSP60 expression but no identifiable difference in relative expression between stage or grade of the individual cancers.

The prognostic significance of HSP60 in cervical cancer caused was assessed by 2-DE, semi-quantitative reverse transcriptase polymerase chain reaction (RT-PCR) and WB analyses (Hwang et al., 2009). The results from 2-DE proteomics, confirmed by WB analyses $(P<0.05)$, suggest that HSP60 may be involved in the development of cervical cancer.

Autoantibodies may be an excellent tool for the early diagnosis of cancer. Many studies have investigated the tumor-associated autoimmune response to identify new early diagnostic markers. In breast cancer patients, ELISA experiments showed the presence

Table 1 | Selection of recent publications assessing HSP27 as a biomarker in cancers.

\begin{tabular}{|c|c|c|c|c|}
\hline Sample type & Cancer type & Total number of samples & Assay & Finding/claim (References) \\
\hline Biopsy & Prostate & 97 patients & $\mathrm{IHC}$ & $\begin{array}{l}\text { HSP27 expression level was significantly associated with Gleason score, } \\
\text { but not with studied factors before radical prostatectomy (Miyake et al., } \\
\text { 2006) }\end{array}$ \\
\hline Tissue & Prostate & 120 patients; 60 controls & $\mathrm{IHC}$ & $\begin{array}{l}\text { The level of HSP27 expression was correlated with their Gleason grade and } \\
\text { associated with poor clinical outcome (Cornford et al., 2000) }\end{array}$ \\
\hline Tissue & Bladder & 42 patients; 10 controls & $\mathrm{IHC}$ & $\begin{array}{l}\text { No correlation between HSP27 expression and grade was found (Lebret } \\
\text { et al., 2003) }\end{array}$ \\
\hline Tissue & $\mathrm{HCC}$ & 38 patients & $\mathrm{IHC}, \mathrm{DI}$ & $\begin{array}{l}\text { HSP27 expression increased with the progression of hepatitis B virus- } \\
\text { related HCC (Lim et al., 2005) }\end{array}$ \\
\hline Tissue & Prostate & 193 patients & $\mathrm{IHC}$ & $\begin{array}{l}\text { HSP27 expression significantly associated with several conventional prog- } \\
\text { nostic factors (Miyake et al., 2010) }\end{array}$ \\
\hline Serum & Breast & 32 patients; 26 controls & ELISA & $\begin{array}{l}\text { Higher levels of HSP27 released in the tumor microenvironment compared } \\
\text { to serum levels of cancer patients (Banerjee et al., 2011) }\end{array}$ \\
\hline Serum & Breast & 76 patients; 54 controls & $\begin{array}{l}\text { 2-DE; MALDI- } \\
\text { TOF-MS }\end{array}$ & $\begin{array}{l}\text { HSP27 was up-regulated in the serum of breast cancer patients (Rui et al., } \\
\text { 2003) }\end{array}$ \\
\hline Serum & Ovarian & 158 patients; 80 controls & ELISA & $\begin{array}{l}\text { The mean concentration of anti-HSP27 antibodies was significantly higher } \\
\text { than in the control group (Olejek et al., 2009) }\end{array}$ \\
\hline
\end{tabular}

Techniques are: 2-DE, two-dimensional gel electrophoresis; DI, dot immunoblot; ELISA, enzyme-linked immunosorbent assay, IHC, immunohistochemical analyses; MALDI-TOF-MS, matrix-assisted laser desorption/ionization - time-of-flight-mass spectrometry. HCC stands for hepatocellular carcinoma. 
of autoantibodies against HSP60 and the level of serum HSP60 antibodies was found to be dependent on the cancer grade. Interestingly, high grade tumors showed a more elevated level of HSP60 autoantibodies compared to low-grade tumors. HSP60 mRNA levels were significantly higher in primary breast cancer compared to healthy breast tissues. Using IHC, it was found that HSP60 expression increased from normal to invasive tissues (Desmetz et al., 2008). Based on a serological proteomics-based approach, a humoral immune response in patients with breast cancer related to HSP60 was found (Hamrita et al., 2008). These authors looked for the presence of IgG antibodies against MCF-7 cell line proteins. They found a higher level for the molecular chaperone HSP60. In line with these results, IHC analyses performed on breast cancer biopsies showed increased expression of HSP60 in tumors of advanced clinical stage when compared with earlier stage carcinomas (Isidoro et al., 2005). These results support the fact that HSP60 overexpression during the initial stages of breast carcinogenesis may be clinically relevant for the early diagnosis of breast cancer. HSP60 was also identified by antibodies in sera from patients with chronic hepatitis, liver cirrhosis, or hepatocellular carcinoma.
However, HSP60 antibodies in precancer conditions were not a useful candidate as a biomarker for pancreatic cancer. Further investigations should be performed to determine the quantitative changes of this chaperone protein associated with early events leading to tumorigenesis (Looi et al., 2008). In colorectal carcinoma, the elevated expression of HSP60 showed a significant association with tumor differentiation, and may indicate a worse prognosis (Mori et al., 2005).

The correlation of HSP60 expression with tumor growth and/or progression makes this chaperone protein a potential biomarker. However, more efforts should be devoted to quantitative analyses of HSP60 expression to resolve existing contradictory findings concerning its association with a good or a poor prognosis (see Table 2).

\section{HSP70}

The HSP70 superfamily consists of at least 13 members (Kampinga et al., 2009). Inducible HSP70 (HSPA1A or HSP72), an extensively studied, powerful ATP-dependent chaperone with key antiapoptotic properties (Garrido et al., 2006; Didelot et al., 2007;

Table 2 | Selection of recent publications assessing HSP60 as a biomarker in cancers.

\begin{tabular}{|c|c|c|c|c|}
\hline Sample type & Cancer type & Total number of samples & Assay & Finding/claim (References) \\
\hline Biopsy & Prostate & 107 patients & WB; IHC & $\begin{array}{l}\text { HSP60 is overexpressed in tumors and strongly associated } \\
\text { with prognostic clinical parameters (Castilla et al., 2010) }\end{array}$ \\
\hline Tissue & Cervical & 20 patients; 20 controls & $\begin{array}{l}\text { 2-DE; RT-PCR; } \\
\text { WB }\end{array}$ & Increased HSP60 expression (Hwang et al., 2009) \\
\hline Tissue & Prostate & 289 patients & IHC; TMA & $\begin{array}{l}\text { HSP60 overexpression was correlated with both biochem- } \\
\text { ical recurrence and Gleason score (Glaessgen et al., 2008) }\end{array}$ \\
\hline Tissue & Bladder & 42 patients; 10 controls & $\mathrm{IHC}$ & $\begin{array}{l}\text { HSP60 low expression levels correlated with higher tumor } \\
\text { stage. Loss of HSP60 expression was correlated with } \\
\text { tumor infiltration (Lebret et al., 2003) }\end{array}$ \\
\hline Tissue & Breast & 149 patients & $\mathrm{IHC} ; \mathrm{TMA}$ & $\begin{array}{l}\text { No association was found between HSP60 and prognosis } \\
\text { (Sebastiani et al., 2006) }\end{array}$ \\
\hline Tissue & Colorectal & 44 patients & $\begin{array}{l}\text { CDNA } \\
\text { microarray; } \\
\text { IHC }\end{array}$ & $\begin{array}{l}\text { A significant association of HSP60 with tumor differentia- } \\
\text { tion and pT stage was observed (Mori et al., 2005) }\end{array}$ \\
\hline Tissue, cell line & Prostate & 120 patients; 60 controls & $\mathrm{IHC} ; \mathrm{WB}$ & $\begin{array}{l}\text { No correlation was found between levels of HSP60 expres- } \\
\text { sion and phenotypic behavior of individual primary prosta- } \\
\text { tic cancers (Cornford et al., 2000) }\end{array}$ \\
\hline Tissue & Breast & 101 patients; 13 controls & WB; IHC & $\begin{array}{l}\text { Increased expression of HSP60 compared with controls. } \\
\text { HSP60 correlated with patient overall survival (Isidoro } \\
\text { et al., 2005) }\end{array}$ \\
\hline Tissue & $\mathrm{HCC}$ & 38 patients & $\mathrm{IHC}, \mathrm{DI}$ & $\begin{array}{l}\text { Expression of HSP60 decreased during hepatocarcinogen- } \\
\text { esis (Lim et al., 2005) }\end{array}$ \\
\hline $\begin{array}{l}\text { Serum, tissue, } \\
\text { cell line }\end{array}$ & $\begin{array}{l}\text { Breast; ovarian; prostate; } \\
\text { ductal carcinoma }\end{array}$ & 147 patients; 93 controls & $\begin{array}{l}\text { ELISA; } 2-\mathrm{DE} ; \\
\text { WB; } \\
\text { IHC }\end{array}$ & $\begin{array}{l}\text { HSP60 was overexpressed during the first steps of breast } \\
\text { carcinogenesis (Desmetz et al., 2008) }\end{array}$ \\
\hline Serum cell line & Breast & 40 patients; 42 controls & $\begin{array}{l}\text { IHC; } \quad \text { MALDI- } \\
\text { TOF-MS; } \\
\text { 2-DE }\end{array}$ & $\begin{array}{l}\text { Significantly higher level of autoantibodies against HSP60 } \\
\text { in breast cancer patient sera (Hamrita et al., 2008) }\end{array}$ \\
\hline
\end{tabular}

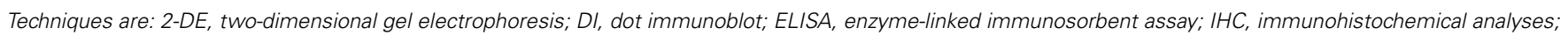

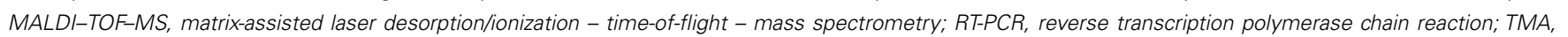
tissue microarray; WB, western blot. 
Seigneuric et al., 2011). HSP70 could be an interesting biomarker because its overexpression in serum is associated with many cancers. However, these studies are mostly qualitative. HSP70 is considered to be the most universally stress inducible HSP (Suzuki et al., 2006) with reported inductions of over 200-fold (Modi et al., 2007). A few clinical articles provide quantitative data on HSP70 expression based on ELISA tests (see Table 3). The relatively large case-control study nested in the Japan Collaborative Cohort Study for Evaluation of Cancer Risk (Suzuki et al., 2006) reports HSP70 levels in the serum of lung cancer patients in comparison with the C-reactive protein (CRP). The data indicate mean levels of $2.41 \mathrm{ng} / \mathrm{mL}(n=189)$ for cases versus $2.01 \mathrm{ng} / \mathrm{mL}(n=377)$ for controls. This is to be compared to smaller differences in the CRP levels: $0.92 \mathrm{ng} / \mathrm{mL}(n=209)$ versus $0.81 \mathrm{ng} / \mathrm{mL}(n=425)$ respectively (Suzuki et al., 2006). In colorectal cancer, the difference in serum levels of HSP70 between patients who survived $(1.51 \mathrm{ng} / \mathrm{mL}, n=95)$ compared to patients who did not survive $(1.84 \mathrm{ng} / \mathrm{mL}, n=84)$ was reported to be significant $(P=0.014$; Kocsis et al., 2010). ELISA-determined concentrations of serum HSP70 autoantibody were reported to be significantly higher in esophageal squamous cell carcinoma (ESCC) patients $(0.412 \mathrm{mg} / \mathrm{mL}, n=16)$ than for patients with gastric cancer $(0.236 \mathrm{mg} / \mathrm{mL}, n=17, P<0.001)$, colon cancer $(0.231 \mathrm{mg} / \mathrm{mL}, n=19, P<0.001)$, or healthy individuals $(0.207 \mathrm{mg} / \mathrm{mL}, n=13, P<0.001$; Fujita et al., 2008). Albeit limited in the number of patients and controls, this study suggests the presence of autoantibody against HSP70 in the serum of ESCC patients.

\section{HSP9O}

HSP90 is an ATP-dependent chaperone that has been highly studied for anticancer therapy (Kamal et al., 2003; Solit and Chiosis, 2008; Jego et al., 2010) with targeted inhibitors being tested in clinical trials in phase II/III. HSP90 ensures the quality control of many proteins involved in cell-signaling pathways. It is also essential for the stability and function of many oncogenic client proteins (Taipale et al., 2010). Its expression in malignant cells is reported to be high and constitutive, suggesting a crucial role in survival and growth of cancer cells (Whitesell and Lindquist, 2005). Studies have investigated the potential prognostic value of HSP90 in different cancers as shown in Table 4. In invasive breast cancers, immunohistochemical analyses showed that HSP90 was abundantly expressed in all tumor samples included in the study (Song et al., 2010). A trend toward correlation $(P=0.062)$ was identified between HSP90 expression and diminished relapse-free survival (RFS) in the triple negative subtype (HER-, ER-, PR-). In patients with HER+ (tumors HER2-clustered), the coexpression of HSP90 and PI3K-p110 (or loss of PTEN) predicted a significantly decreased RFS. In line with these results, it was suggested that HSP90 overexpression in malignant breast cancer was associated with decreased survival (Pick et al., 2007). Concerning hepatocellular carcinoma, Lim et al. (2005) suggested that HSP90 expression increases along with the progression of hepatocarcinogenesis. In fact, HSP90 expression showed a strong correlation with prognostic factors of hepatocellular carcinoma, being associated with vascular invasion and metastasis. Similar findings were observed in bladder cancer, where HSP90 level was correlated with

Table 3 | Selection of recent publications assessing HSP70 as a biomarker in cancers.

\begin{tabular}{|c|c|c|c|c|}
\hline Sample type & Cancer type & Total number of samples & Assay & Finding/claim (References) \\
\hline Tissue & Bladder & 42 patients; 10 controls & $\mathrm{IHC}$ & $\begin{array}{l}\text { No correlation was found with tumor grade, disease stage, and } \\
\text { patient outcome (Lebret et al., 2003) }\end{array}$ \\
\hline Tissue & Prostate & 120 patients; 60 controls & $\mathrm{IHC}$ & $\begin{array}{l}\text { No correlation was found between levels of HSP70 expression } \\
\text { and phenotypic behavior of individual primary prostatic cancers } \\
\text { (Cornford et al., 2000) }\end{array}$ \\
\hline Tissue & $\mathrm{HCC}$ & 38 patients & IHC, DI & $\begin{array}{l}\text { Positive correlation between HSP70 expression and prognostic } \\
\text { factors of hepatitis B virus-related HCC (Lim et al., 2005) }\end{array}$ \\
\hline Serum & Colorectal & 179 patients & ELISA & $\begin{array}{l}\text { Serum level of soluble HSP70 may be a stage-independent } \\
\text { prognostic marker in colorectal cancer without distant metas- } \\
\text { tasis (Kocsis et al., 2010) }\end{array}$ \\
\hline
\end{tabular}

Techniques are: 2-DE, two-dimensional gel electrophoresis; ELISA, enzyme-linked immunosorbent assay; IHC, immunohistochemical analyses; MALDI-TOF-MS, matrix-assisted laser desorption/ionization - time-of-flight-mass spectrometry; DI, dot immunoblot; WB, western blot. ESCC, esophageal squamous cell carcinoma; HCC, hepatocellular carcinoma. 
high grade tumor (Lebret et al., 2003). In studies on ovarian cancer, HSP90 expression was associated with higher stages, and so may be a good indicator of aggressiveness when associated with other HSPs (Elpek et al., 2003).

HSPS AS BIOMARKERS: HEADING FOR GOLD (STANDARDS)? The ever increasing body of data dealing with HSPs reflects their potential as both therapeutic targets and as biomarkers. We have highlighted only some of the many interesting points, and identified some pitfalls that are recurrent in many research fields (Ioannidis, 2005; Mischak et al., 2010), and which should be addressed to clarify future work concerning HSP detection.

For the validation of most results presented here, it is crucial that large-scale studies be performed to confirm these findings (Ioannidis, 2005; Mischak et al., 2010). This review of recent research articles on HSP detection in cancer reveals that the most frequently used techniques are essentially qualitative. Overall, IHC staining seems the most frequently used, regardless of the HSP of interest. The two main disadvantages of IHC staining are that the results are qualitative and subjective, like any image analysis. ELISA tests should be favored to provide more objective, quantitative data.

How specific are HSPs as biomarkers in cancer? HSPs are key proteins that tend to be overexpressed in response to a large panel of stressors. They are thus by definition not specific to cancer. However, it is shown that HSPs are necessary for cancer cell survival, making cancer cells in fact addicted to these cytoprotective chaperones. As a consequence, cancer cells express high levels of HSPs compared to normal cells, and need them for survival. It is clear that no single biomarker will be sufficient to detect cancer, its relapse or monitor a treatment (Seigneuric et al., 2010). An alternative, then, is to combine different biomarkers on the same level, (e.g., at the protein level) as exemplified by DNA microarrays and "omics" in general (Seigneuric et al., 2009). Another way to deal with the inherent lack of specificity of a single protein is to combine it with biomarkers from

Table 4 | Selection of recent publications assessing HSP90 as a biomarker in cancers.

\begin{tabular}{|c|c|c|c|c|}
\hline Sample type & Cancer type & Total number of samples & Assay & Finding/claim (References) \\
\hline Tissue & Bladder & 42 patients; 10 controls & $\mathrm{IHC}$ & HSP90 expression levels correlated with tumor infiltration (Lebret et al., 2003) \\
\hline Tissue & $\mathrm{HCC}$ & 38 patients & IHC; DI & $\begin{array}{l}\text { Positive correlation between HSP90 expression and prognostic factors of hepati- } \\
\text { tis B virus-related HCC (Lim et al., 2005) }\end{array}$ \\
\hline Tissue & Breast & 212 patients & $\mathrm{IHC}$ & $\begin{array}{l}\text { Expression of HSP90 was associated with 5-year relapse-free survival (RFS). } \\
\text { Coexpression of HSP90 and PI3K or expression of HSP90 along with PTEN } \\
\text { loss demonstrated prognostic significance in terms of RFS in patients with } \\
\text { HER2-positive cancers, but not with HER2-negative cancer (Song et al., 2010) }\end{array}$ \\
\hline Tissue & $\mathrm{RCC}$ & 153 patients & $\mathrm{IHC}$ & $\begin{array}{l}\text { HSP90 was expressed in most RCC specimens. No significant association with } \\
\text { conventional diagnostic factors (Sakai et al., 2009) }\end{array}$ \\
\hline Tissue & Prostate & 193 patients & $\mathrm{IHC}$ & $\begin{array}{l}\text { No significant association of HSP90 expression levels with conventional diagnos- } \\
\text { tic factors (Miyake et al., 2010) }\end{array}$ \\
\hline Tissue & Ovarian & 52 patients & $\mathrm{IHC}$ & $\begin{array}{l}\text { HSP90 expression was associated with higher stages but did not correlate with } \\
\text { prognosis (Elpek et al., 2003) }\end{array}$ \\
\hline Tissue cell line & Breast & 655 patients & $\mathrm{IHC}$; WB & $\begin{array}{l}\text { High HSP90 expression was associated with decreased survival in primary breast } \\
\text { cancer (Pick et al., 2007) }\end{array}$ \\
\hline
\end{tabular}

Techniques are: IHC, immunohistochemical analyses; DI, dot immunoblot; WB, western blot. HCC, hepatocellular carcinoma; RCC, renal cell carcinoma.

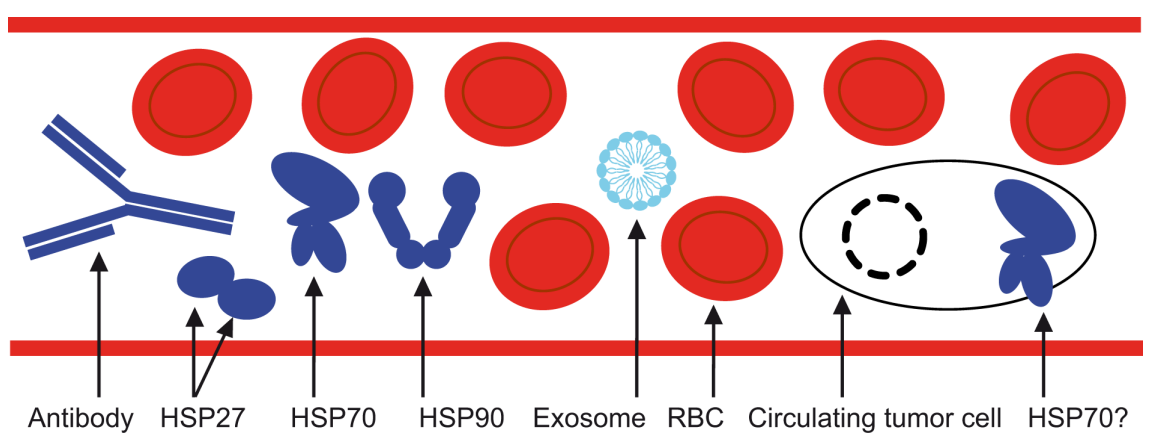

FIGURE 2 | Peripheral blood is a biological fluid of high interest for HSP detection in oncology since its composition besides red blood cells or RBCs is reported to include, circulating HSP antibodies and autoantibodies, HSP27, HSP70, and HSP90, as well as tumor-derived exosomes expressing HSP70 at the membrane. The presence of circulating tumor cells expressing HSP70 at their membrane remains to be demonstrated but may be complementary to the EpCAM biomarker, which is currently in clinical trials. 
other levels (see Figure 2). For instance, HSP expression at the protein level could be integrated with the measurement of tumorderived exosomes expressing HSP70 in the membrane. Circulating tumor cells (CTCs) represent another very interesting level. Critical to embryogenesis, cancer cells are thought to undergo an epithelial-to-mesenchymal transition (EMT) during carcinogenesis, contributing to invasion and metastasis (Thiery, 2002; Thiery et al., 2009). Indeed, altered cell-cell and cell-extracellular interactions would enable: (i) the release of epithelial cells, or the "seed" (Fidler, 2003) from the surrounding tissue, (e.g., primary tumor), (ii) entering the circulation (intravasation), (iii) exiting the circulation (extravasation), (iv) the colonization of distant organs (Fidler, 2003). Current clinical investigations into the detection of CTCs are based on the cell receptor EpCAM (Seigneuric et al., 2010). However, EpCAM expression is supposed to decrease during the circulation of CTCs in peripheral blood (or lymph), as reported with flow cytometry experiments (Rao et al., 2005). This may lead to suboptimal detection of CTCs. The process of EMT is well documented in cell lines and mice experiments, but its clinical relevance remains debated (Ledford, 2011). In contrast to normal cells, epithelial cancer cells circulating in a liquid environment should have increased levels of membrane HSP. Although this hypothesis remains to be tested, it would represent an interesting means to robustly detect CTCs based on HSPs expression at the cell membrane. HSP70 is a strong candidate as various cancer cell lines express a fragment of HSP70 at their membrane that can be detected by an antibody (Stangl et al., 2011). This is of high interest for cancer detection, as it enables a means of characterization by flow cytometry and ELISA tests.

Heat shock proteins are essential proteins that are highly conserved, but their expression levels between individuals is reported to differ widely for HSP60 (Shamaei-Tousi et al., 2007), HSP70 (Modi et al., 2007), and/or HSP90 (Ramanathan et al., 2010). The problem of this intrinsic variability in HSP expression may be circumvented by using time series, assessing HSPs with longitudinal data by following-up every single patient as a function of time. In order to compare HSP levels between patients, adjusting for age, gender, and ethnicity may be necessary. The role of circulating HSP70 and/or HSP70 antibodies in the peripheral circulation in the context of aging is interesting (Pockley et al., 1998). Reported ranges of HSP70 expression largely differ. Indeed, discrepancies up to a few orders of magnitude, varying from a few $\mathrm{ng} / \mathrm{mL}$ (Terry et al., 2006) to values 10 to a 100 times higher were reported (Rea et al., 2001; Njemini et al., 2005), possibly due to ELISA matrix defects (Njemini et al., 2005). However, the serum concentration of HSP70 is reported to decrease with age (Rea et al., 2001; Macario and Conway de Macario, 2005; Terry et al., 2006; Njemini et al., 2011) as is serum HSP60 (Macario and Conway de Macario, 2005). The gender issue should be also addressed. For instance, a 3.5 times higher expression of circulating HSP60 was found in women's peripheral blood compared to men (Macario and Conway de Macario, 2005). In addition, HSP70 serum concentrations in women were about twice those in men (Pockley et al., 1998). The study of Suzuki et al. (2006) reported differences in serum HSP70 levels in cancer patients. The authors reported $2.46 \mathrm{ng} / \mathrm{mL}(n=146)$ in male versus $2.25 \mathrm{ng} / \mathrm{mL}(n=43)$ in females. For healthy controls however, serum HSP70 levels were quite similar: $2.00 \mathrm{ng} / \mathrm{mL}$ $(n=285)$ and $2.06 \mathrm{ng} / \mathrm{mL}(n=92)$ respectively (Suzuki et al., 2006).

For an HSP to qualify as a cancer biomarker, its expression level must be compared to gold standards or to commonly assessed biomolecules. A circulating HSP should be compared to other proteins such as CRP, a systemic and non-specific marker of chronic inflammation (Chaturvedi et al., 2010) used daily in practice, or CA 15-3 (cancer antigen 15-3) or CA125 (cancer antigen 125), which are widely used biomarkers for breast (Duffy, 2006) and ovarian cancer (Petricoin et al., 2002), respectively.

\section{CONCLUDING REMARKS}

Research studies in cancer detection rely heavily on the identification of proteins, but how many proteins are in fact uniquely expressed by cancer but not normal cells? Presumably, their proteomes are shared at least to some extent, thus favoring quantitative rather than qualitative techniques to reveal subtle differences in expression levels currently found in the pico- to sub-nanomolar range (Krueger, 2006). It is likely that HSPs will not discern different cancer types. However, this may be seen as the major advantage of HSPs: a potentially universal family of cancer biomarkers.

Since the data amassed during the past half century is essentially qualitative, it is too early to suggest which HSP or combination of HSPs may show promise in the future. Yet, even though many studies focus on HSP60, we suggest focusing rather on inducible HSPs that are seldom present in non-stressed normal cells. Among these, HSP70 seems to be particularly interesting as it is the most abundant inducible HSP in cancer cells and is also present in the membrane of cancer cells but not in non-transformed cells. In contrast to the common strategy relying on the combination of several cancer biomarkers (Fung et al., 2007; Seigneuric et al., 2009, 2010), HSP70 could allow a detection at different levels: circulating protein, tumor-derived exosomes, and CTCs. Of course, these assays need to be optimized and standardized. Furthermore, their sensitivity and specificity should be addressed. As we recently have shown, another interesting inducible HSP may be HSP110 whose expression can be used for the diagnosis of colon cancer patients presenting micro-satellite instability (Dorard et al., 2011).

Because many HSP studies utilize a small number of samples, there is a real need to coordinate studies and conduct large prospective clinical trials assessing for diagnosis, follow-up, or response to treatment not only HSPs but also other potential biomarkers simultaneously using quantitative methods. One option is the design of surface plasmon resonance techniques measuring several proteins in parallel (Seigneuric et al., 2010) as well as tumor-exosomes and CTCs in biological fluids.

These are new and interesting frontiers worth investigating that may offer the opportunity to detect cancer early danger signals.

\section{ACKNOWLEDGMENTS}

This work was supported by Ligue Nationale contre le Cancer (LNCC), Conseil Régional de Bourgogne, and the European Commission's Seventh Framework Programme (SPEDOC 248835). Carmen Garrido's team has the Label d'excellence de la LNCC. 


\section{REFERENCES}

Arispe, N., Doh, M., Simakova, O., Kurganov, B., and De Maio, A. (2004). Hsc70 and Hsp70 interact with phosphatidylserine on the surface of PC12 cells resulting in a decrease of viability. FASEB J. 18, 1636-1645.

Banerjee, S., Lin, C. F., Skinner, K. A., Schiffhauer, L. M., Peacock, J., Hicks, D. G., Redmond, E. M., Morrow, D., Huston, A., Shayne, M., Langstein, H. N., Miller-Graziano, C. L., Strickland, J., O'Donoghue, L., and De, A. K. (2011). Heat shock protein 27 differentiates tolerogenic macrophages that may support human breast cancer progression. Cancer Res. 71, 318-327.

Basu, S., Binder, R. J., Suto, R., Anderson, K. M., and Srivastava, P. K. (2000). Necrotic but not apoptotic cell death releases heat shock proteins, which deliver a partial maturation signal to dendritic cells and activate the NFkappa B pathway. Int. Immunol. 12, 1539-1546.

Bruey, J. M., Ducasse, C., Bonniaud, P., Ravagnan, L., Susin, S. A., DiazLatoud, C., Gurbuxani, S., Arrigo, A. P., Kroemer, G., Solary, E., and Garrido, C. (2000). Hsp27 negatively regulates cell death by interacting with cytochrome c. Nat. Cell Biol. 2, 645-652.

Calderwood, S. K. (2010). Heat shock proteins in breast cancer progression - a suitable case for treatment? Int. J. Hyperthermia 26, 681-685.

Castilla, C., Congregado, B., Conde, J. M., Medina, R., Torrubia, F. J., Japon, M. A., and Saez, C. (2010). Immunohistochemical expression of Hsp60 correlates with tumor progression and hormone resistance in prostate cancer. Urology 76, e1-e6.

Chalmin, F., Ladoire, S., Mignot, G., Vincent, J., Bruchard, M., RemyMartin, J. P., Boireau, W., Rouleau, A., Simon, B., Lanneau, D., De Thonel, A., Multhoff, G., Hamman, A., Martin, F., Chauffert, B., Solary, E., Zitvogel, L., Garrido, C., Ryffel, B., Borg, C., Apetoh, L., Rebe, C., and Ghiringhelli, F. (2010). Membrane-associated Hsp72 from tumor-derived exosomes mediates STAT3-dependent immunosuppressive function of mouse and human myeloid-derived suppressor cells. J. Clin. Invest. 120, 457-471.

Chaturvedi, A. K., Caporaso, N. E., Katki, H. A., Wong, H. L., Chatterjee, N., Pine, S. R., Chanock, S. J., Goedert, J. J., and Engels, E. A. (2010). C-reactive protein and risk of lung cancer. J. Clin. Oncol. 28, 2719-2726.

Ciocca, D. R., and Calderwood, S. K. (2005). Heat shock proteins in cancer: diagnostic, prognostic, predictive, and treatment implications. Cell Stress Chaperones 10, 86-103.

Cornford, P. A., Dodson, A. R., Parsons, K. F., Desmond, A. D., Woolfenden, A., Fordham, M., Neoptolemos, J. P., Ke, Y., and Foster, C. S. (2000). Heat shock protein expression independently predicts clinical outcome in prostate cancer. Cancer Res. 60, 7099-7105.

De Maio, A. (2011). Extracellular heat shock proteins, cellular export vesicles, and the stress observation system: a form of communication during injury, infection, and cell damage. It is never known how far a controversial finding will go! Dedicated to Ferruccio Ritossa. Cell Stress Chaperones 16, 235-249.

Desmetz, C., Bibeau, F., Boissiere, F., Bellet, V., Rouanet, P., Maudelonde, T., Mange, A., and Solassol, J. (2008). Proteomics-based identification of HSP60 as a tumor-associated antigen in early stage breast cancer and ductal carcinoma in situ. J. Proteome Res. 7, 3830-3837.

Di Tommaso, L., Destro, A., Seok, J. Y., Balladore, E., Terracciano, L., Sangiovanni, A., Iavarone, M., Colombo, M., Jang, J. J., Yu, E., Jin, S. Y., Morenghi, E., Park, Y. N., and Roncalli, M. (2009). The application of markers (HSP70 GPC3 and GS) in liver biopsies is useful for detection of hepatocellular carcinoma. $J$. Hepatol. 50, 746-754.

Didelot, C., Lanneau, D., Brunet, M., Joly, A. L., De Thonel, A., Chiosis, G., and Garrido, C. (2007). Anti-cancer therapeutic approaches based on intracellular and extracellular heat shock proteins. Curr. Med. Chem. 14, 2839-2847.

Dorard, C., de Thonel, A., Collura, A., Marisa, L., Svrcek, M., Lagrange, A., Jego, G., Wanherdrick, K., Joly, A. L., Buhard, O., Gobbo, J., PenardLacronique, V., Zouali, H., Tubacher, E., Kirzin, S., Selves, J., Milano, G., Etienne-Grimaldi, M. C., BengrineLefèvre, L., Louvet, C., Tournigand, C., Lefèvre, J. H., Parc, Y., Tiret, E., Fléjou, J. F., Gaub, M. P., Garrido, C., and Duval, A. (2011). Expression of a mutant HSP110 sensitizes colorectal cancer cells to chemotherapy and improves disease prognosis. Nat. Med. doi: 10.1038/nm.2457. [Epub ahead of print].

Duffy, M. J. (2006). Serum tumor markers in breast cancer: are they of clinical value? Clin. Chem. 52, 345-351.

Elpek, G. O., Karaveli, S., Simsek, T., Keles, N., and Aksoy, N. H. (2003). Expression of heat-shock proteins hsp27, hsp70 and hsp90 in malignant epithelial tumour of the ovaries. APMIS 111, 523-530.
Evdonin, A. L., Martynova, M. G., Bystrova, O. A., Guzhova, I. V., Margulis, B. A., and Medvedeva, N. D. (2006). The release of Hsp70 from A431 carcinoma cells is mediated by secretory-like granules. Eur. J. Cell Biol. 85, 443-455.

Fidler, I. J. (2003). The pathogenesis of cancer metastasis: the "seed and soil" hypothesis revisited. Nat. Rev. Cancer 3, 453-458.

Fujita, Y., Nakanishi, T., Miyamoto, Y., Hiramatsu, M., Mabuchi, H., Miyamoto, A., Shimizu, A., Takubo, T., and Tanigawa, N. (2008). Proteomics-based identification of autoantibody against heat shock protein 70 as a diagnostic marker in esophageal squamous cell carcinoma. Cancer Lett. 263, 280-290.

Fung, G., Seigneuric, R., Krishnan, S., Rao, R. B., Wouters, B. G., and Lambin, P. (2007). "Reducing a biomarkers list via mathematical programming: application to gene signatures to detect time-dependent hypoxia in cancer," in Icmla 2007: Sixth International Conference On Machine Learning And Applications, Proceedings, Cincinnati, OH, 482-487.

Gallucci, S., and Matzinger, P. (2001). Danger signals: SOS to the immune system. Curr. Opin. Immunol. 13, 114-119.

Garrido, C., Brunet, M., Didelot, C., Zermati, Y., Schmitt, E., and Kroemer, G. (2006). Heat shock proteins 27 and 70: anti-apoptotic proteins with tumorigenic properties. Cell Cycle 5, 2592-2601.

Ghayour-Mobarhan, M., Saber, H., and Ferns, G. A. (2011). The potential role of heat shock protein 27 in cardiovascular disease. Clin. Chim. Acta. doi:10.1016/j.cca.2011.04.005. [Epub ahead of print].

Glaessgen, A., Jonmarker, S., Lindberg, A., Nilsson, B., Lewensohn, R., Ekman, P., Valdman, A., and Egevad, L. (2008). Heat shock proteins 27,60 and 70 as prognostic markers of prostate cancer. APMIS 116, 888-895.

Hamrita, B., Chahed, K., Kabbage, M., Guillier, C. L., Trimeche, M., Chaieb, A., and Chouchane, L. (2008). Identification of tumor antigens that elicit a humoral immune response in breast cancer patients' sera by serological proteome analysis (SERPA). Clin. Chim. Acta 393, 95-102.

Hightower, L. E., and Guidon, P. T. Jr. (1989). Selective release from cultured mammalian cells of heatshock (stress) proteins that resemble glia-axon transfer proteins. J. Cell. Physiol. 138, 257-266.

Hunter-Lavin, C., Davies, E. L., Bacelar, M. M., Marshall, M. J., Andrew,
S. M., and Williams, J. H. (2004). Hsp70 release from peripheral blood mononuclear cells. Biochem. Biophys. Res. Commun. 324, 511-517.

Hwang, Y. J., Lee, S. P., Kim, S. Y., Choi, Y. H., Kim, M. J., Lee, C. H., Lee, J. Y., and Kim, D. Y. (2009). Expression of heat shock protein $60 \mathrm{kDa}$ is upregulated in cervical cancer. Yonsei Med. J. 50, 399-406.

Ioannidis, J. P. (2005). Why most published research findings are false. PLoS. Med. 2, e124. doi:10.1371/journal.pmed.0020124

Isidoro, A., Casado, E., Redondo, A., Acebo, P., Espinosa, E., Alonso, A. M., Cejas, P., Hardisson, D., Fresno Vara, J. A., Belda-Iniesta, C., Gonzalez-Baron, M., and Cuezva, J. M. (2005). Breast carcinomas fulfill the Warburg hypothesis and provide metabolic markers of cancer prognosis. Carcinogenesis 26, 2095-2104.

Jego, G., Hazoumé, A., Seigneuric, R., and Garrido, C. (2010). Targeting heat shock proteins in cancer. Cancer Lett. [Epub ahead of print].

Joly, A. L., Wettstein, G., Mignot, G., Ghiringhelli, F., and Garrido, C. (2010). Dual role of heat shock proteins as regulators of apoptosis and innate immunity. J. Innate Immun. 2, 238-247.

Kamal, A., Thao, L., Sensintaffar, J., Zhang, L., Boehm, M. F., Fritz, L. C., and Burrows, F. J. (2003). A highaffinity conformation of Hsp90 confers tumour selectivity on Hsp90 inhibitors. Nature 425, 407-410.

Kampinga, H. H., Hageman, J., Vos, M. J., Kubota, H., Tanguay, R. M., Bruford, E. A., Cheetham, M. E., Chen, B., and Hightower, L. E. (2009). Guidelines for the nomenclature of the human heat shock proteins. Cell Stress Chaperones 14, 105-111.

Khalil, A. A., Kabapy, N. F., Deraz, S. F., and Smith, C. (2011). Heat shock proteins in oncology: diagnostic biomarkers or therapeutic targets? Biochim. Biophys. Acta 1816, 89-104.

Kocsis, J., Madaras, B., Toth, E. K., Fust, G., and Prohaszka, Z. (2010). Serum level of soluble $70-\mathrm{kD}$ heat shock protein is associated with high mortality in patients with colorectal cancer without distant metastasis. Cell Stress Chaperones 15, 143-151.

Krueger, K. E. (2006). The potential of serum proteomics for detection of cancer: promise or only hope? Onkologie 29, 498-499.

Langdon, S. P., Rabiasz, G. J., Hirst, G. L., King, R. J., Hawkins, R. A., Smyth, J. F., and Miller, W. R. (1995). Expression of the heat shock protein HSP27 in human ovarian cancer. Clin. Cancer Res. 1, 1603-1609. 
Lanneau, D., Wettstein, G., Bonniaud, P., and Garrido, C. (2010). Heat shock proteins: cell protection through protein triage. ScientificWorldJournal 10, 1543-1552.

Lebret, T., Watson, R. W., Molinie, V., O'Neill, A., Gabriel, C., Fitzpatrick, J. M., and Botto, H. (2003). Heat shock proteins HSP27, HSP60, HSP70, and HSP90: expression in bladder carcinoma. Cancer 98, 970-977.

Ledford, H. (2011). Cancer theory faces doubts. Nature 472, 273.

Lee, I. N., Chen, C. H., Sheu, J. C., Lee, H. S., Huang, G. T., Yu, C. Y., Lu, F. J., and Chow, L. P. (2005). Identification of human hepatocellular carcinoma-related biomarkers by two-dimensional difference gel electrophoresis and mass spectrometry. J. Proteome Res. 4, 2062-2069.

Lim, S. O., Park, S. G., Yoo, J. H., Park, Y. M., Kim, H. J., Jang, K. T., Cho, J. W., Yoo, B. C., Jung, G. H., and Park, C. K. (2005). Expression of heat shock proteins (HSP27, HSP60, HSP70, HSP90, GRP78, GRP94) in hepatitis $B$ virus-related hepatocellular carcinomas and dysplastic nodules. World J. Gastroenterol. 11, 2072-2079.

Looi, K. S., Nakayasu, E. S., Diaz, R. A., Tan, E. M., Almeida, I. C., and Zhang, J. Y. (2008). Using proteomic approach to identify tumorassociated antigens as markers in hepatocellular carcinoma. J. Proteome Res. 7, 4004-4012.

Macario, A. J., Cappello, F., Zummo, G., and Conway de Macario, E. (2011). Chaperonopathies of senescence and the scrambling of interactions between the chaperoning and the immune systems. Ann. N. Y. Acad. Sci. 1197, 85-93.

Macario, A. J., and Conway de Macario, E. (2004). The pathology of cellular anti-stress mechanisms: a new frontier. Stress 7, 243-249.

Macario, A. J., and Conway de Macario, E. (2005). Sick chaperones, cellular stress, and disease. N. Engl. J. Med. 353, 1489-1501.

Mambula, S. S., and Calderwood, S. K. (2006). Heat shock protein 70 is secreted from tumor cells by a nonclassical pathway involving lysosomal endosomes. J. Immunol. 177, 7849-7857.

Mischak, H., Allmaier, G., Apweiler, R., Attwood, T., Baumann, M., Benigni, A., Bennett, S. E., Bischoff, R., Bongcam-Rudloff, E., Capasso, G., Coon, J. J., D’Haese, P., Dominiczak, A. F., Dakna, M., Dihazi, H., Ehrich, J. H., Fernandez-Llama, P., Fliser, D., Frokiaer, J., Garin, J., Girolami, M., Hancock, W. S., Haubitz, M., Hochstrasser, D., Holman,
R. R., Ioannidis, J. P., Jankowski, J., Julian, B. A., Klein, J. B., Kolch, W., Luider, T., Massy, Z., Mattes, W. B., Molina, F., Monsarrat, B., Novak, J., Peter, K., Rossing, P., Sanchez-Carbayo, M., Schanstra, J. P., Semmes, O. J., Spasovski, G., Theodorescu, D., Thongboonkerd, V., Vanholder, R., Veenstra, T. D. Weissinger, E., Yamamoto, T., and Vlahou, A. (2010). Recommendations for biomarker identification and qualification in clinical proteomics. Sci. Transl. Med. 2, $46 \mathrm{ps} 42$.

Miyake, H., Muramaki, M., Kurahashi, T., Takenaka, A., and Fujisawa, M. (2010). Expression of potential molecular markers in prostate cancer: correlation with clinicopathological outcomes in patients undergoing radical prostatectomy. Urol. Oncol. 28, 145-151.

Miyake, H., Muramaki, M., Kurahashi, T., Yamanaka, K., Hara, I., and Fujisawa, M. (2006). Enhanced expression of heat shock protein 27 following neoadjuvant hormonal therapy is associated with poor clinical outcome in patients undergoing radical prostatectomy for prostate cancer. Anticancer Res. 26, 1583-1587.

Modi, S., Stopeck, A. T., Gordon, M. S., Mendelson, D., Solit, D. B., Bagatell, R., Ma, W., Wheler, J., Rosen, N., Norton, L., Cropp, G. F., Johnson, R. G., Hannah, A. L., and Hudis, C. A. (2007). Combination of trastuzumab and tanespimycin (17AAG, KOS-953) is safe and active in trastuzumab-refractory HER-2 overexpressing breast cancer: a phase I dose-escalation study. J. Clin. Oncol. 25, 5410-5417.

Mori, D., Nakafusa, Y., Miyazaki, K., and Tokunaga, O. (2005). Differential expression of Janus kinase 3 (JAK3), matrix metalloproteinase 13 (MMP13), heat shock protein 60 (HSP60), and mouse double minute 2 (MDM2) in human colorectal cancer progression using human cancer cDNA microarrays. Pathol. Res. Pract. 201, 777-789.

Nickel, W., and Seedorf, M. (2008). Unconventional mechanisms of protein transport to the cell surface of eukaryotic cells. Annu. Rev. Cell Dev. Biol. 24, 287-308.

Njemini, R., Bautmans, I., Onyema, O. O., Van Puyvelde, K., Demanet, C., and Mets, T. (2011). Circulating heat shock protein 70 in health, aging and disease. BMC Immunol. 12, 24. doi:10.1186/1471-2172-12-24

Njemini, R., Demanet, C., and Mets, T. (2005). Comparison of two ELISAs for the determination of Hsp70 in serum. J. Immunol. Methods 306, 176-182.

Olejek, A., Damasiewicz-Bodzek, A., Bodzek, P., Wielkoszynski, T., Zamlynski, J., Stoltny, P., and Skutil, M. (2009). Concentrations of antibodies against heat shock protein 27 in the sera of women with ovarian carcinoma. Int. J. Gynecol. Cancer 19, 1516-1520.

Petricoin, E. F., Ardekani, A. M., Hitt, B. A., Levine, P. J., Fusaro, V. A., Steinberg, S. M., Mills, G. B., Simone, C., Fishman, D. A., Kohn, E. C., and Liotta, L. A. (2002). Use of proteomic patterns in serum to identify ovarian cancer. Lancet 359, 572-577.

Pick, E., Kluger, Y., Giltnane, J. M. Moeder, C., Camp, R. L., Rimm, D. L., and Kluger, H. M. (2007) High HSP90 expression is associated with decreased survival in breast cancer. Cancer Res. 67, 2932-2937.

Pockley, A. G., Shepherd, J., and Corton, J. M. (1998). Detection of heat shock protein 70 (Hsp70) and antiHsp70 antibodies in the serum of normal individuals. Immunol. Invest. 27, 367-377.

Ramanathan, R. K., Egorin, M. J., Erlichman, C., Remick, S. C., Ramalingam, S. S., Naret, C., Holleran, J. L., TenEyck, C. J., Ivy, S. P., and Belani, C. P. (2010). Phase I pharmacokinetic and pharmacodynamic study of 17-dimethylaminoethylamino17-demethoxygeldanamycin, an inhibitor of heat-shock protein 90, in patients with advanced solid tumors. J. Clin. Oncol. 28, 1520-1526.

Rao, C. G., Chianese, D., Doyle, G. V., Miller, M. C., Russell, T., Sanders, R. A. Jr., and Terstappen, L. W. (2005). Expression of epithelial cell adhesion molecule in carcinoma cells present in blood and primary and metastatic tumors. Int. J. Oncol. 27, 49-57.

Rea, I. M., McNerlan, S., and Pockley, A. G. (2001). Serum heat shock protein and anti-heat shock protein antibody levels in aging. Exp. Gerontol. 36, 341-352.

Rui, Z., Jian-Guo, J., Yuan-Peng, T., Hai, P., and Bing-Gen, R. (2003). Use of serological proteomic methods to find biomarkers associated with breast cancer. Proteomics 3, 433-439.

Sakai, I., Miyake, H., Takenaka, A., and Fujisawa, M. (2009). Expression of potential molecular markers in renal cell carcinoma: impact on clinicopathological outcomes in patients undergoing radical nephrectomy. BJU Int. 104, 942-946.

Schilling, D., Gehrmann, M., Steinem, C., De Maio, A., Pockley, A. G.
Abend, M., Molls, M., and Multhoff, G. (2009). Binding of heat shock protein 70 to extracellular phosphatidylserine promotes killing of normoxic and hypoxic tumor cells. FASEB J. 23, 2467-2477.

Schmitt, E., Gehrmann, M., Brunet, M., Multhoff, G., and Garrido, C. (2007). Intracellular and extracellular functions of heat shock proteins: repercussions in cancer therapy. J. Leukoc. Biol. 81, 15-27.

Sebastiani, V., Botti, C., Di Tondo, U., Visca, P., Pizzuti, L., Santeusanio, G., and Alo, P. L. (2006). Tissue microarray analysis of FAS, Bcl-2, Bcl-x, ER, PgR, Hsp60, p53 and Her2-neu in breast carcinoma. Anticancer Res. 26, 2983-2987.

Seigneuric, R., Gobbo, J., Colas, P., and Garrido, C. (2011). Targeting cancer with peptide aptamers. Oncotarget 2, 557-561.

Seigneuric, R., Markey, L., Nuyten, D. S., Dubernet, C., Evelo, C. T., Finot, E., and Garrido, C. (2010). From nanotechnology to nanomedicine: applications to cancer research. Curr. Mol. Med. 10, 640-652.

Seigneuric, R., van Riel, N. A. W., Starmans, M. H. W., van Erk, A., Evelo, C. T. A., Wouters, B. G., and Lambin, P. (2009). Systems Biology Applied to Cancer Research. Hershey, NY: Medical Information Science Reference.

Shamaei-Tousi, A., Steptoe, A., O’Donnell, K., Palmen, J., Stephens, J. W., Hurel, S. J., Marmot, M., Homer, K., D’Aiuto, F., Coates, A. R. Humphries, S. E., and Henderson, B. (2007). Plasma heat shock protein 60 and cardiovascular disease risk: the role of psychosocial, genetic, and biological factors. Cell Stress Chaperones 12, 384-392.

Solit, D. B., and Chiosis, G. (2008). Development and application of Hsp90 inhibitors. Drug Discov. Today 13, 38-43.

Song, C. H., Park, S. Y., Eom, K. Y., Kim, J. H., Kim, S. W., Kim, J. S., and Kim, I. A. (2010). Potential prognostic value of heat-shock protein 90 in the presence of phosphatidylinositol3-kinase overexpression or loss of PTEN, in invasive breast cancers. Breast Cancer Res. 12, R20.

Stangl, S., Gehrmann, M., Riegger, J., Kuhs, K., Riederer, I., Sievert, W., Hube, K., Mocikat, R., Dressel, R., Kremmer, E., Pockley, A. G., Friedrich, L., Vigh, L., Skerra, A., and Multhoff, G. (2011). Targeting membrane heat-shock protein 70 (Hsp70) on tumors by cmHsp70.1 antibody. Proc. Natl. Acad. Sci. U.S.A. $108,733-738$. 
Suzuki, K., Ito, Y., Wakai, K., Kawado, M., Hashimoto, S., Seki, N., Ando, M., Nishino, Y., Kondo, T., Watanabe, Y., Ozasa, K., Inoue, T., and Tamakoshi, A. (2006). Serum heat shock protein 70 levels and lung cancer risk: a case-control study nested in a large cohort study. Cancer Epidemiol. Biomarkers Prev. 15, 1733-1737.

Taipale, M., Jarosz, D. F., and Lindquist, S. (2010). HSP90 at the hub of protein homeostasis: emerging mechanistic insights. Nat. Rev. Mol. Cell Biol. 11, 515-528.

Terry, D. F., Wyszynski, D. F., Nolan, V. G., Atzmon, G., Schoenhofen, E. A., Pennington, J. Y., Andersen, S. L., Wilcox, M. A., Farrer, L. A., Barzilai, N., Baldwin, C. T., and Asea, A. (2006). Serum heat shock protein
70 level as a biomarker of exceptional longevity. Mech. Ageing Dev. 127, 862-868.

Thiery, J. P. (2002). Epithelialmesenchymal transitions in tumour progression. Nat. Rev. Cancer 2, 442-454.

Thiery, J. P., Acloque, H., Huang, R. Y., and Nieto, M. A. (2009). Epithelial-mesenchymal transitions in development and disease. Cell 139, 871-890.

Vega, V. L., Rodriguez-Silva, M., Frey, T., Gehrmann, M., Diaz, J. C., Steinem, C., Multhoff, G., Arispe, N., and De Maio, A. (2008). Hsp70 translocates into the plasma membrane after stress and is released into the extracellular environment in a membrane-associated form that activates macrophages. J. Immunol. 180, 4299-4307.
Whitesell, L., and Lindquist, S. L. (2005). HSP90 and the chaperoning of cancer. Nat. Rev. Cancer 5, 761-772.

Willis, M. S., and Patterson, C. (2010). Hold me tight: role of the heat shock protein family of chaperones in cardiac disease. Circulation 122, 1740-1751.

$\mathrm{Xu}$, L., Chen, S., and Bergan, R. C. (2006). MAPKAPK2 and HSP27 are downstream effectors of p38 MAP kinase-mediated matrix metalloproteinase type 2 activation and cell invasion in human prostate cancer. Oncogene 25, 2987-2998.

Conflict of Interest Statement: The authors declare that the research was conducted in the absence of any commercial or financial relationships that could be construed as a potential conflict of interest.
Received: 29 July 2011; accepted: 30 September 2011; published online: 10 November 2011.

Citation: Seigneuric R, Mjahed H, Gobbo $J$, Joly A-L, Berthenet K, Shirley $S$ and Garrido $C$ (2011) Heat shock proteins as danger signals for cancer detection. Front. Oncol. 1:37. doi 10.3389/fonc.2011.00037

This article was submitted to Frontiers in Molecular and Cellular Oncology, a specialty of Frontiers in Oncology.

Copyright (C) 2011 Seigneuric, Mjahed, Gobbo, Joly, Berthenet, Shirley and Garrido. This is an open-access article subject to a non-exclusive license between the authors and Frontiers Media $S A$, which permits use, distribution and reproduction in other forums, provided the original authors and source are credited and other Frontiers conditions are complied with. 